\title{
Group 11 complexes with the 1,1'Bis[N,N'-(2-(diphenylphosphino) amide] ferrocene ligand
}

\author{
Javier E. Aguado', M. Concepción Gimeno ${ }^{1}$, Antonio Laguna' ${ }^{1}$, M. Dolores Villacampa $^{1}$ \\ www.goldbulletin.org
}

\begin{abstract}
The ligand 1,1-bis[N,N'-(2-diphenylphosphino) amide]ferrocene, $\mathrm{Fc}\left(\mathrm{CONHCH}_{2} \mathrm{CH}_{2} \mathrm{PPh}_{2}\right)_{2} \quad$ (L), has been synthesized by reaction of the chloro carbonyl derivative $\mathrm{Fc}(\mathrm{COCl})_{2}$ and the aminophosphine $\mathrm{NH}_{2} \mathrm{CH}_{2} \mathrm{CH}_{2} \mathrm{PPh}_{2}$. The coordination properties towards silver(I), gold(I) and gold(III) compounds have been explored. Several complexes with the diphosphine acting as bidentate chelating or bridgind ligand have been prepared. Furthermore the dinuclear species $\left[\mathrm{Au}_{2}\left\{\mathrm{Fc}\left(\mathrm{CONCH} \mathrm{CH}_{2} \mathrm{PPh}_{2}\right)_{2}\right\}\right]$ with the ligand coordinated through the phosphorus and the deprotonated amido group have been achieved.
\end{abstract}

\section{Introduction}

Ferrocene is a very versatile molecule with important properties such as high electron density, aromaticity and redox reversibility. These characteristics, together with the ease of preparation of mono and $1,1^{\prime}$-disubstituted ferrocene derivatives with a great variety of organic fragments that may contain O, N, S, $P$, etc. as donor atoms, make ferrocene a very suitable building block in many fields of research (1). Current areas of interest in ferrocene chemistry include the use in catalysis, materials and bioinorganic chemistry. These functionalized ferrocene derivatives and the study of their coordination to metal centres are an important topic of research in many areas that seek special properties of such species, e.g. nonlinear optical properties, charge transport, liquid crystals, electrochemical recognition, catalysis, nanoparticles, immunoassay reagents or biological applications (1-15).

Phosphorus-substituted ferrocenes are the most well-studied class of heteroatom substituted ferrocenes and much of the attention has been focused in the chemistry of 1,1'- bis(diphenylphosp hino)ferrocene (dppf) and chiral phosphines because the potential applications in catalysis (1).

Hemilabile ferrocene phosphines are not very common and as far as we are aware only the phosphine-ether or thioether derivatives $\mathrm{FC}\left(\mathrm{ECH}_{2} \mathrm{CH}_{2} \mathrm{PPh}_{2}\right)_{2}(\mathrm{E}=\mathrm{O}$, S) has been reported (16). Here we report on the synthesis of a hemilabile amide-phosphine disubstituted ferrocene derivative $\mathrm{Fc}\left(\mathrm{CONHCH} \mathrm{CH}_{2} \mathrm{PPh}_{2}\right)_{2}$ and their coordination properties towards silver(I) and gold(I) compounds. The species $\left[\mathrm{Au}_{2}\left\{\mu-\mathrm{Fc}\left(\mathrm{CONCH}_{2} \mathrm{CH}_{2} \mathrm{PPh}_{2}\right)_{2}\right\}\right]$, in which the amides have been deprotonated, and the ligand is acting as N,N,P,P tetradentate has been synthesized.
Departamento de Química Inorgánica, Instituto de Ciencia de Materiales de Aragón, Universidad de Zaragoza-C.S.I.C., E-50009 Zaragoza, Spain 


\section{Experimental section}

Instrumentation. Infrared spectra were recorded in the range $4000-200 \mathrm{~cm}^{-1}$ on a Perkin-Elmer 883 spectrophotometer using Nujol mulls between polyethylene sheets. C, H, N and S analyses were carried out with a Perkin-Elmer 2400 microanalyzer. Mass spectra were recorded on a VG Autospec, with the liquid secondary-ion mass spectra (LSIMS) technique, using nitrobenzyl alcohol as matrix. NMR spectra were recorded on a Varian Unity 300 spectrometer and a Bruker ARX 300 spectrometer in $\mathrm{CDCl} 3$, otherwise stated. Chemical shifts are cited relative to $\mathrm{SiMe}_{4}\left({ }^{1} \mathrm{H}\right.$, external), $\mathrm{CFCl}{ }_{3}\left({ }^{19} \mathrm{~F}\right.$, external) and $85 \% \mathrm{H}_{3} \mathrm{PO}_{4}\left({ }^{31} \mathrm{P}\right.$, external).

Starting materials. The starting materials $\mathrm{Fc}(\mathrm{COCl})_{2}$ (17), $\left[\mathrm{Cu}(\mathrm{NCMe})_{4}\right] \mathrm{PF}_{6}$ (18), [O( $\left.\left(\mathrm{AuPPh}_{3}\right)_{3}\right] \mathrm{ClO}_{4}(19)$, [AuCl(tht)] (20), [Au( $\left(\mathrm{C}_{6} \mathrm{~F}_{5}\right)$ (tht)] (21), $\left[\mathrm{Au}\left(\mathrm{C}_{6} \mathrm{~F}_{5}\right)_{3}\right.$ (tht)] (22), [Au(tht) $)_{2}$ OTf (23), [Ag(OTf) $\left.\left(\mathrm{PR}_{3}\right)\right]$ (24) were prepared according to published procedures. $\left[\mathrm{Au}(\mathrm{OTf})\left(\mathrm{PPh}_{3}\right)\right]$ was obtained by reaction of $\left[\mathrm{AuCl}\left(\mathrm{PPh}_{3}\right)\right]$ with $\mathrm{Ag}(\mathrm{OTf})$ in dichloromethane and used in situ. All other reagents were commercially available.

\section{Synthesis of $\mathrm{Fc}\left(\mathrm{CONHCH}_{2} \mathrm{CH}_{2} \mathrm{PPh}_{2}\right)_{2}(\mathrm{~L})$}

To a solution of $\mathrm{PPh}_{2} \mathrm{CH}_{2} \mathrm{CH}_{2} \mathrm{NH}_{2}$ (1.218 g, 5.3 $\mathrm{mmol}$ ) in $20 \mathrm{~mL}$ of dichloromethane was added $\mathrm{NEt}_{3}$ ( $0.556 \mathrm{~g}, 5.5 \mathrm{mmol}$ ) under an argon atmosphere and then the mixture was cooled to $0^{\circ} \mathrm{C}$. To this mixture was added dropwise a solution of 1,1'-bis (chlorocarbonyl) ferrocene $(0.827 \mathrm{~g}, 2.6 \mathrm{mmol})$ in dichloromethane. After the addition the mixture was left to reach room temperature and stirred for $24 \mathrm{~h}$. Then a saturated solution of $\mathrm{NaHCO}_{3}$ in water was added and the organic phase was separated. Evaporation of the solvent to ca. $3 \mathrm{~mL}$ and addition of diethyl ether gave the ligand $\mathrm{L}$ as an orange solid. Yield, $0.947 \mathrm{~g}$, $52 \%$. Elemental analysis (\%), $\mathrm{C}_{40} \mathrm{H}_{38} \mathrm{FeN}_{2} \mathrm{O}_{2} \mathrm{P}_{2}$ (696.17): calcd. C, 68.94; H, 5.50; N, 4.02; found: C, 69.17; H, 5.70; N, 14.14. NMR data. ${ }^{1} \mathrm{H}, \delta: 2.60(\mathrm{~m}, 4 \mathrm{H}$, $\left.-\mathrm{CH}_{2} \mathrm{P}-\right), 3.62\left(\mathrm{~m}, 4 \mathrm{H},-\mathrm{CH}_{2} \mathrm{~N}-\right), 4.33\left(\mathrm{~m}, 4 \mathrm{H}, \alpha-\mathrm{C}_{5} \mathrm{H}_{4}\right)$, $4.51\left(\mathrm{~m}, 4 \mathrm{H}, \beta-\mathrm{C}_{5} \mathrm{H}_{4}\right), 7.12(\mathrm{~m}, \mathrm{br}, 2 \mathrm{H}, \mathrm{NH}), 7.25$ (m, 20H, Ph). ${ }^{31} \mathrm{P}\left\{{ }^{1} \mathrm{H}\right\}, \delta:-19.0(\mathrm{~s}, 2 \mathrm{P}) \mathrm{Hz}$.

\section{Synthesis of [ $\mathrm{Cu}\left\{\mathrm{Fc}\left(\mathrm{CONHCH}_{2}\right.\right.$ $\left.\left.\left.\mathrm{CH}_{2} \mathrm{PPh}_{2}\right)_{2}\right\}\right] \mathrm{PF} 6$ (1) and [Ag(OTf) $\{\mathrm{Fc}$ $\left.\left.\left(\mathrm{CONHCH}_{2} \mathrm{CH}_{2} \mathrm{PPh}_{2}\right)_{2}\right\}\right]$ (2)}

To a solution of the ligand $\mathrm{Fc}\left(\mathrm{CONHCH} \mathrm{CH}_{2} \mathrm{PPh}_{2}\right)_{2}$ $(0.069 \mathrm{~g}, 0.1 \mathrm{mmol})$ in $20 \mathrm{ml}$ of dichloromethane was added $\left[\mathrm{Cu}(\mathrm{NCMe})_{4}\right] \mathrm{PF}_{6}(0.038 \mathrm{~g}, 0.1 \mathrm{mmol})$ or $\mathrm{Ag}(\mathrm{OTf})(0.025 \mathrm{~g}, 0.1 \mathrm{mmol})$ and the mixture, protected from the light, was stirred for $30 \mathrm{~min}$. The solution was evaporated to ca. $3 \mathrm{ml}$ and the addition of diethyl ether gave orange solids of complexes 1 or 2. Complex 1: Yield, $0.074 \mathrm{~g}, 82 \%$. Elemental analysis (\%), $\mathrm{C}_{40} \mathrm{H}_{38} \mathrm{CuF}_{6} \mathrm{FeN}_{2} \mathrm{O}_{2} \mathrm{P}_{3}$ (904.07): calcd. C, 53.09; $\mathrm{H}, 4.23$; N, 3.09; found: C, 52.96; H, 4.42; $\mathrm{N}$, 3.19. NMR data. ${ }^{1} \mathrm{H}, \delta$ : $2.52\left(\mathrm{~m}, 4 \mathrm{H},-\mathrm{CH}_{2} \mathrm{P}-\right), 3.49$ $\left(\mathrm{m}, 4 \mathrm{H},-\mathrm{CH}_{2} \mathrm{~N}-\right), 4.34\left(\mathrm{~m}, 4 \mathrm{H}, \alpha-\mathrm{C}_{5} \mathrm{H}_{4}\right), 4.66(\mathrm{~m}, 4 \mathrm{H}$, $\left.\beta-\mathrm{C}_{5} \mathrm{H}_{4}\right), 7.14(\mathrm{~m}, 2 \mathrm{H}, \mathrm{Ph}), 7.45(\mathrm{~m}, \mathrm{br}, 2 \mathrm{H}, \mathrm{NH})$. ${ }^{31} \mathrm{P}\left\{{ }^{1} \mathrm{H}\right\}, \delta:-8.0$ (s, br, 2P) Hz.

Complex 2: Yield, 0.067 g, $71 \%$. Elemental analysis (\%), $\mathrm{C}_{41} \mathrm{H}_{38} \mathrm{AgFF}_{3} \mathrm{FeN}_{2} \mathrm{O}_{5} \mathrm{P}_{2} \mathrm{~S}$ (953.472): calcd. C, 51.64; H, 4.01; N, 2.93; S, 3.36; found: C, 52.01; H, 4.63; $\mathrm{N}, 2.87$; $\mathrm{S}, 3.31 . \mathrm{NMR}$ data. ${ }^{1} \mathrm{H}, \delta$ : $2.64(\mathrm{~m}, 4 \mathrm{H}$, $\left.-\mathrm{CH}_{2} \mathrm{P}-\right), 3.54\left(\mathrm{~m}, 4 \mathrm{H},-\mathrm{CH}_{2} \mathrm{~N}-\right), 4.25\left(\mathrm{~m}, 4 \mathrm{H}, \alpha-\mathrm{C}_{5} \mathrm{H}_{4}\right)$, $4.61\left(\mathrm{~m}, 4 \mathrm{H}, \beta-\mathrm{C}_{5} \mathrm{H}_{4}\right), 7.30(\mathrm{~m}, 2 \mathrm{OH}, \mathrm{Ph}), 7.79(\mathrm{~m}, \mathrm{br}$, $2 \mathrm{H}, \mathrm{NH}) .{ }^{31} \mathrm{P}\{1 \mathrm{H}\}, \delta:-1.0(\mathrm{~s}, \mathrm{br}, 2 \mathrm{P}) \mathrm{Hz}$.

\section{Synthesis of [Ag(OTf) $\left\{\mathrm{Fc}\left(\mathrm{CONHCH}_{2} \mathrm{CH}_{2}\right.\right.$ $\left.\left.\left.\mathrm{PPh}_{2}\right)_{2}\right\}\left(\mathrm{PPh}_{3}\right)\right](3)$}

To a solution of the ligand $\mathrm{Fc}\left(\mathrm{CONHCH} \mathrm{CH}_{2} \mathrm{PPh}_{2}\right)_{2}$ $(0.069 \mathrm{~g}, 0.1 \mathrm{mmol})$ in $20 \mathrm{ml}$ of dichloromethane was added $\left[\mathrm{Ag}(\mathrm{OTf})\left(\mathrm{PPh}_{3}\right)\right](0.051 \mathrm{~g}, 0.1 \mathrm{mmol})$ and the mixture, protected from the light, was stirred for 30 min. The solution was evaporated to ca. $3 \mathrm{ml}$ and the addition of diethyl ether gave an orange solid of complex 3. Yield, $0.088 \mathrm{~g}, 73 \%$. Elemental analysis (\%), $\mathrm{C}_{59} \mathrm{H}_{53} \mathrm{AgF}_{3} \mathrm{FeN}_{2} \mathrm{O}_{5} \mathrm{P}_{3} \mathrm{~S} \quad$ (1214.12): calcd. C, 58.31; H, 4.39; N, 2.30; S, 2.63; found: C, 58.23; H, 4.65; N, 2.14; S, 2.63. NMR data. ${ }^{1} \mathrm{H}$,

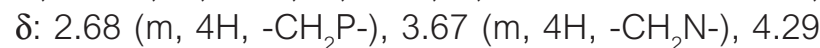
$\left(m, 4 \mathrm{H}, \alpha-\mathrm{C}_{5} \mathrm{H}_{4}\right), 4.67\left(\mathrm{~m}, 4 \mathrm{H}, \beta-\mathrm{C}_{5} \mathrm{H}_{4}\right), 7.40(\mathrm{~m}$, $35 \mathrm{H}, \mathrm{Ph}), 8.12(\mathrm{~m}, \mathrm{br}, 2 \mathrm{H}, \mathrm{NH}) .{ }^{31} \mathrm{P}\left\{{ }^{1} \mathrm{H}\right\}, \delta: 5.0$ and $-6.0(\mathrm{br}, 3 \mathrm{P}) \mathrm{Hz}$.

\section{Synthesis of $\left[\mathrm{Au}_{2} \mathrm{X}_{2}\left\{\mu-\mathrm{Fc}\left(\mathrm{CONHCH}_{2}\right.\right.\right.$ $\left.\left.\left.\mathrm{CH}_{2} \mathrm{PPh}_{2}\right)_{2}\right\}\right]\left(\mathrm{X}=\mathrm{Cl}(4), \mathrm{C}_{6} \mathrm{~F}_{5}(5)\right)$}

To a solution of the ligand $\mathrm{Fc}\left(\mathrm{CONHCH} \mathrm{CH}_{2} \mathrm{PPh}_{2}\right)_{2}$ $(0.069 \mathrm{~g}, 0.1 \mathrm{mmol})$ in $20 \mathrm{ml}$ of dichloromethane was added [AuCl(tht)] (0.064 g, $0.2 \mathrm{mmol}$ ) or $\left[\mathrm{Au}\left(\mathrm{C}_{6} \mathrm{~F}_{5}\right)\right.$ (tht) $](0.090 \mathrm{~g}, 0.2 \mathrm{mmol})$ and the mixture was stirred for $30 \mathrm{~min}$. Evaporation of the solvent to ca. $2 \mathrm{ml}$ yield to orange solids of $\mathbf{4}$ or $\mathbf{5}$. Complex 4: Yield, 0.128 g, 80 \%. Elemental analysis (\%), $\mathrm{C}_{40} \mathrm{H}_{38} \mathrm{Au}_{2} \mathrm{Cl}_{2} \mathrm{FeN}_{2} \mathrm{O}_{2} \mathrm{P}_{2}$ (1160.04): calcd. C, 41.37; H, 3.30; N, 2.41; found: C, 41.71; H, 3.42; N, 2.33. NMR data. ${ }^{1} \mathrm{H}, \delta: 2.80\left(\mathrm{~m}, 4 \mathrm{H},-\mathrm{CH}_{2} \mathrm{P}-\right), 3.75$ $\left(\mathrm{m}, 4 \mathrm{H},-\mathrm{CH}_{2} \mathrm{~N}-\right), 4.58\left(\mathrm{~m}, 8 \mathrm{H}, \mathrm{C}_{5} \mathrm{H}_{4}\right), 7.21(\mathrm{~m}, \mathrm{br}, 2 \mathrm{H}$, $\mathrm{NH}), 7.60(\mathrm{~m}, 2 \mathrm{OH}, \mathrm{Ph}) .{ }^{31} \mathrm{P}\left\{{ }^{1} \mathrm{H}\right\}, \delta: 24.6(\mathrm{~s}, 2 \mathrm{P}) \mathrm{Hz}$. 


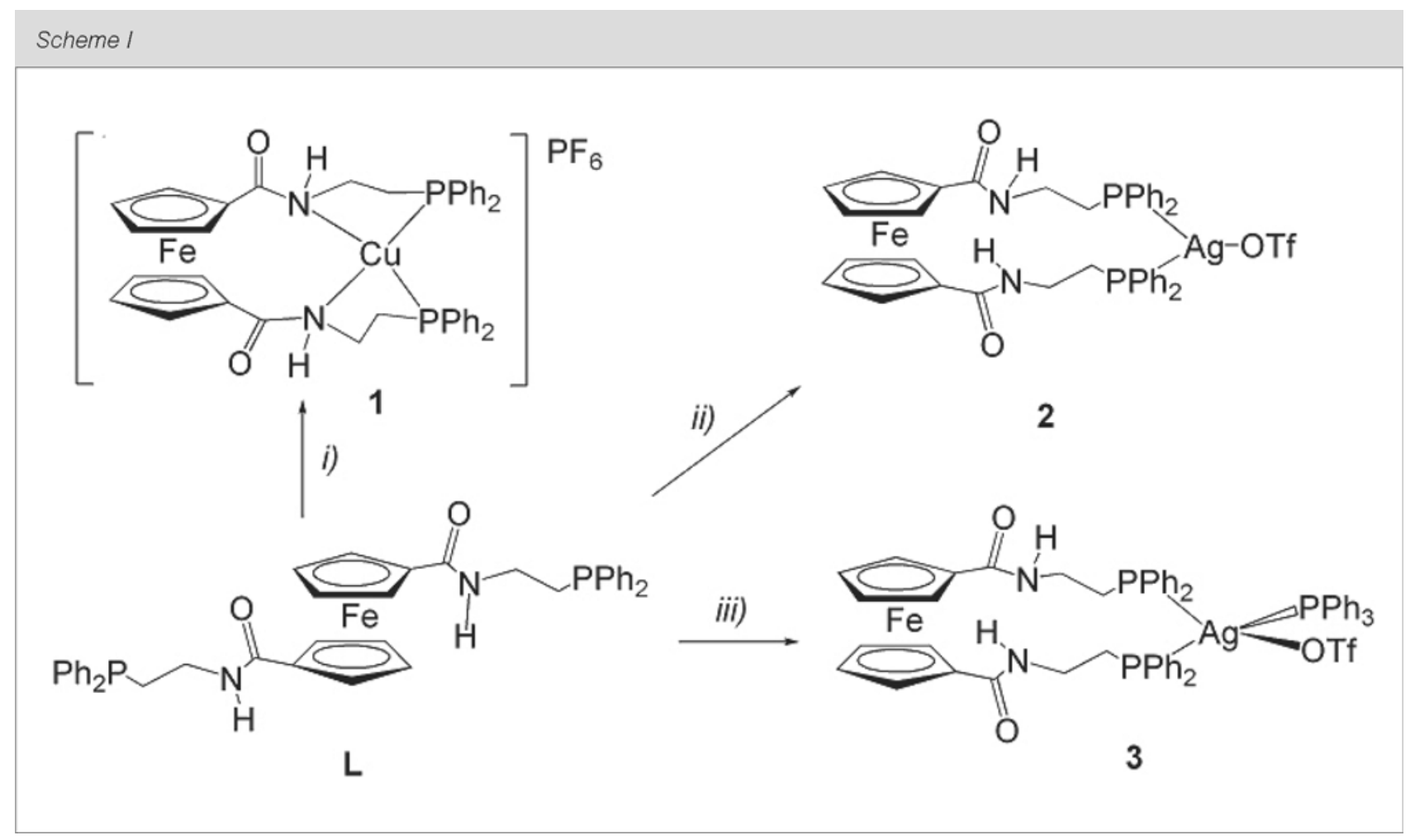

i) $\left[\mathrm{Cu}(\mathrm{NCMe})_{4}\right] \mathrm{PF}_{6}$, ii) $\mathrm{Ag}(\mathrm{OTf})$, iii) $\left[\mathrm{Ag}(\mathrm{OTf})\left(\mathrm{PPh}_{3}\right)\right]$

Complex 5: Yield, $0.117 \mathrm{~g}, 83 \%$. Elemental analysis (\%), $\mathrm{C}_{52} \mathrm{H}_{38} \mathrm{Au}_{2} \mathrm{~F}_{10} \mathrm{FeN}_{2} \mathrm{O}_{2} \mathrm{P}_{2}$ (1424.09): calcd. C, 43.81; H, 2.68; N, 1.96; found: C, 44.04; H, 2.41; N, 1.57. NMR data. ${ }^{1} \mathrm{H}, \delta: 3.00\left(\mathrm{~m}, 4 \mathrm{H},-\mathrm{CH}_{2} \mathrm{P}-\right), 3.78$ $\left(\mathrm{m}, 4 \mathrm{H},-\mathrm{CH}_{2} \mathrm{~N}-\right), 4.25\left(\mathrm{~m}, 4 \mathrm{H}, \alpha-\mathrm{C}_{5} \mathrm{H}_{4}\right), 4.57(\mathrm{~m}, 4 \mathrm{H}$, $\left.\beta-\mathrm{C}_{5} \mathrm{H}_{4}\right), 7.31$ (m, br, 2H, NH), 7.40-7.80 (m, 2OH, Ph). ${ }^{31} \mathrm{P}\left\{{ }^{1} \mathrm{H}\right\}, \delta: 32.7$ (s, 2P) Hz. ${ }^{19} \mathrm{~F}, \delta:-115.8(\mathrm{~m}, 4 \mathrm{~F}, \mathrm{o}-\mathrm{F})$, -157.8 (t, 2F, p-F, J(FF) 20.2 Hz), -161.8 (m, 4F, m-F).

\section{Synthesis of $\left[\mathrm{Au}_{2}\left\{\mu-\mathrm{Fc}\left(\mathrm{CONHCH}_{2}\right.\right.\right.$ $\left.\left.\left.\mathrm{CH}_{2} \mathrm{PPh}_{2}\right)_{2}\right\}\left(\mathrm{PPh}_{2}\right)_{2}\right](\mathrm{OTf})_{2}(6)$}

To a solution of the ligand $\mathrm{FC}\left(\mathrm{CONHCH} \mathrm{CH}_{2} \mathrm{PPh}_{2}\right)_{2}$ $(0.069 \mathrm{~g}, 0.1 \mathrm{mmol})$ in $20 \mathrm{ml}$ of dichloromethane was added $\left[\mathrm{Au}(\mathrm{OTf})\left(\mathrm{PPh}_{3}\right)\right](0.121 \mathrm{~g}, 0.2 \mathrm{mmol})$ and the mixture was stirred for $30 \mathrm{~min}$. The solution was evaporated to ca. $3 \mathrm{ml}$ and the addition of diethyl ether gave an orange solid of complex 6. Yield, $0.164 \mathrm{~g}$, $86 \%$. Elemental analysis (\%), $\mathrm{C}_{78} \mathrm{H}_{68} \mathrm{Au}_{2} \mathrm{~F}_{6} \mathrm{FeN}_{2} \mathrm{O}_{8} \mathrm{P}_{4} \mathrm{~S}_{2}$ (1912.19): calcd. C, 48.95; H, 3.58; N, 1.46; S, 3.34; found: C, 49.30; H, 3.82; N, 1.25; S, 3.56. NMR data. ${ }^{1} \mathrm{H}, \delta: 3.07\left(\mathrm{~m}, 4 \mathrm{H},-\mathrm{CH}_{2} \mathrm{P}-\right), 3.92\left(\mathrm{~m}, 4 \mathrm{H},-\mathrm{CH}_{2} \mathrm{~N}-\right)$, $4.03\left(\mathrm{~m}, 4 \mathrm{H}, \alpha-\mathrm{C}_{5} \mathrm{H}_{4}\right), 4.27\left(\mathrm{~m}, 4 \mathrm{H}, \beta-\mathrm{C}_{5} \mathrm{H}_{4}\right), 7.55$ $(\mathrm{m}, 50 \mathrm{H}, \mathrm{Ph}), 8.74(\mathrm{~m}, \mathrm{br}, 2 \mathrm{H}, \mathrm{NH}) .{ }^{31} \mathrm{P}\left\{{ }^{1} \mathrm{H}\right\}, \delta: 39.0$ (s, 2P); $-60^{\circ} \mathrm{C}$ : AB spectrum, JAB $328.0 \mathrm{~Hz}$.

\section{Synthesis of [Au\{ $\mathrm{Fc}\left(\mathrm{CONHCH}_{2}\right.$ $\left.\left.\left.\mathrm{CH}_{2} \mathrm{PPh}_{2}\right)_{2}\right\}\right] \mathrm{ClO}_{4}(7)$}

To a solution of the ligand $\mathrm{FC}\left(\mathrm{CONHCH} \mathrm{CH}_{2} \mathrm{PPh}_{2}\right)_{2}$ $(0.069 \mathrm{~g}, 0.1 \mathrm{mmol})$ in $20 \mathrm{ml}$ of dichloromethane was added $\left[\mathrm{Au}(\mathrm{tht})_{2}\right] \mathrm{ClO}_{4}(0.047 \mathrm{~g}, 0.1 \mathrm{mmol})$ and the mixture was stirred for $30 \mathrm{~min}$. The solution was evaporated to ca. $3 \mathrm{ml}$ and the addition of diethyl ether gave an orange solid of complex 7. Yield, 0.061 g, $62 \%$. Elemental analysis (\%), $\mathrm{C}_{40} \mathrm{H}_{38} \mathrm{AuCIFeN}_{2} \mathrm{O}_{6} \mathrm{P}_{2}$ (992.09): calcd. C, 48.38; H, 3.86; N, 2.82; found: C, 48.15; H, 3.80; N, 2.72. NMR data. ${ }^{1} \mathrm{H}, \delta: 3.05$ (m, 4H, $\left.-\mathrm{CH}_{2} \mathrm{P}-\right), 3.95\left(\mathrm{~m}, 4 \mathrm{H},-\mathrm{CH}_{2} \mathrm{~N}-\right), 3.77\left(\mathrm{~m}, 2 \mathrm{H}, \mathrm{C}_{5} \mathrm{H}_{4}\right)$, $4.21\left(\mathrm{~m}, 4 \mathrm{H}, \mathrm{C}_{5} \mathrm{H}_{4}\right), 4.73\left(\mathrm{~m}, 2 \mathrm{H}, \mathrm{C}_{5} \mathrm{H}_{4}\right), 7.50(\mathrm{~m}, 2 \mathrm{H}$, $\mathrm{Ph}), 8.65(\mathrm{~m}, 2 \mathrm{H}, \mathrm{NH}) .{ }^{31} \mathrm{P}\left\{{ }^{1} \mathrm{H}\right\}, \delta: 37.4(\mathrm{~s}, 2 \mathrm{P})$.

\section{Synthesis of $\left[\mathrm{Au}_{2}\left\{\mathrm{Fc}\left(\mathrm{CONHCH}_{2}\right.\right.\right.$ $\left.\left.\left.\mathrm{CH}_{2} \mathrm{PPh}_{2}\right)_{2}\right\}\right]$ (8)}

To a solution of the ligand $\mathrm{FC}\left(\mathrm{CONCH}_{2} \mathrm{CH}_{2} \mathrm{PPh}_{2}\right)_{2}$ $(0.069 \mathrm{~g}, 0.1 \mathrm{mmol})$ in $20 \mathrm{ml}$ of dichloromethane was added $\left[\mathrm{O}(\text { AuPPh })_{3}\right] \mathrm{ClO}_{4} \quad\left(\begin{array}{llll}0.149 & \text { g, } & 0.1\end{array}\right.$ $\mathrm{mmol}$ ) and the mixture was stirred for $24 \mathrm{~h}$. The solution was evaporated to ca. $3 \mathrm{ml}$ and the addition of diethyl ether gave an orange solid of complex 8. Yield, 0.085g, 79\%. Elemental analysis 
(\%), $\mathrm{C}_{40} \mathrm{H}_{36} \mathrm{Au}_{2} \mathrm{FeN}_{2} \mathrm{O}_{2} \mathrm{P}_{2}$ (1088.09): calcd. C, 44.11; $\mathrm{H}, 3.33$; N, 2.57; found: C, 44.17; H, 3.47; N, 2.68. NMR data. ${ }^{1} \mathrm{H}, \delta: 2.97\left(\mathrm{~m}, 4 \mathrm{H},-\mathrm{CH}_{2} \mathrm{P}-\right), 3.44(\mathrm{~m}, 4 \mathrm{H}$, $\left.-\mathrm{CH}_{2} \mathrm{~N}-\right), 4.24\left(\mathrm{~m}, 2 \mathrm{H}, \mathrm{C}_{5} \mathrm{H}_{4}\right), 4.49\left(\mathrm{~m}, 2 \mathrm{H}, \mathrm{C}_{5} \mathrm{H}_{4}\right), 4.99$ $\left(\mathrm{m}, 2 \mathrm{H}, \mathrm{C}_{5} \mathrm{H}_{4}\right), 5.85\left(\mathrm{~m}, 2 \mathrm{H}, \mathrm{C}_{5} \mathrm{H}_{4}\right), 7.50(\mathrm{~m}, 2 \mathrm{H}, \mathrm{Ph})$. ${ }^{31} \mathrm{P}\left\{{ }^{1} \mathrm{H}\right\}, \delta: 19.2(\mathrm{~s}, 2 \mathrm{P})$.

\section{Synthesis of $\left[\mathrm{Au}_{2}\left(\mathrm{C}_{6} \mathrm{~F}_{5}\right)_{6}\right.$ $\left.\left\{\mu-\mathrm{Fc}\left(\mathrm{CONHCH}{ }_{2} \mathrm{CH}_{2} \mathrm{PPh}_{2}\right)_{2}\right\}\right]$ (9)}

To a solution of the ligand $\mathrm{Fc}\left(\mathrm{CONHCH}_{2} \mathrm{CH}_{2} \mathrm{PPh}_{2}\right)_{2}$ $(0.069 \mathrm{~g}, 0.1 \mathrm{mmol})$ in $20 \mathrm{ml}$ of dichloromethane was added $\left[\mathrm{Au}\left(\mathrm{C}_{6} \mathrm{~F}_{5}\right)_{3}\left(\mathrm{OEt}_{2}\right)\right] \quad(0.144 \mathrm{~g}, \quad 0.2$ $\mathrm{mmol}$ ) and the mixture was stirred for $30 \mathrm{~min}$. The solution was evaporated to ca. $3 \mathrm{ml}$ and the addition of hexane gave an orange solid of complex 9. Yield, $0.125 \mathrm{~g}, 79 \%$. Elemental analysis (\%), $\mathrm{C}_{58} \mathrm{H}_{38} \mathrm{Au}_{2} \mathrm{~F}_{15} \mathrm{FeN}_{2} \mathrm{O}_{2} \mathrm{P}_{2}$ (1591.08): calcd. C, 43.74; H, 2.40; N, 1.76; found: $\mathrm{C}, 43.86 ; \mathrm{H}, 2.43$; $\mathrm{N}, 1.75$. NMR data. ${ }^{1} \mathrm{H}, \delta: 2.89\left(\mathrm{~m}, 4 \mathrm{H},-\mathrm{CH}_{2} \mathrm{P}-\right), 3.32$ $\left(\mathrm{m}, 4 \mathrm{H},-\mathrm{CH}_{2} \mathrm{~N}-\right), 4.28\left(\mathrm{~m}, 4 \mathrm{H}, \alpha-\mathrm{C}_{5} \mathrm{H}_{4}\right), 4.37(\mathrm{~m}$, $\left.2 \mathrm{H}, \beta-\mathrm{C}_{5} \mathrm{H}_{4}\right), 6.87(\mathrm{~m}, 2 \mathrm{H}, \mathrm{NH}), 7.53(\mathrm{~m}, 2 \mathrm{H}, \mathrm{Ph})$. ${ }^{31} \mathrm{P}\left\{{ }^{1} \mathrm{H}\right\}, \delta: 11.3(\mathrm{~s}, 2 \mathrm{P}) .{ }^{19} \mathrm{~F} \delta: 120.7(\mathrm{~m}, 4 \mathrm{~F}, \mathrm{o}-\mathrm{F})$, -122.0 (m, 2F, o-F), -156.7 (t, 2F, J(FF) $20 \mathrm{~Hz}, p-F)$, -157.4 (t, 1F, J(FF) $20 \mathrm{~Hz}, p-\mathrm{F}),-160.4$ (m, 4F, m-F), $-161.3(\mathrm{~m}, 2 \mathrm{~F}, \mathrm{~m}-\mathrm{F})$.

\section{X-Ray structure determination}

The crystal $\left(0.18 \times 0.16 \times 0.12 \mathrm{~mm}^{3}\right)$ was mounted in inert oil on a glass fibre. Data were measured using MoK $\alpha$ radiation $(\lambda=0.71073)$ on a Bruker SMART 1000 CCD diffractometer. Crystal data: $\mathrm{C}_{40} \mathrm{H}_{36} \mathrm{Au}_{2} \mathrm{FeN}_{2} \mathrm{O}_{2} \mathrm{P}_{2}, \quad M=1088.43$, orthorhombic, space group Pnc2, a $=10.2308(9)$, $b=12.3081(11), c=13.9868(12) \AA, U=1761.2(3)$ Å3, $Z=2, T=-173^{\circ} \mathrm{C}, D=2.052 \mathrm{Mg} \mathrm{m}^{-3}, \mu=8.846$ $\mathrm{mm}^{-1}, F(000)=1040,9953$ reflections measured $\left(2 \theta_{\max } 52^{\circ}, \omega\right.$-scans $), 3454$ unique $\left(R_{\text {int }}=0.0454\right)$, absorption corrections based on multiple scans (program SADABS (25)). The structure was solved by heavy-atom method, and subjected to full-matrix least-squares refinement on $F^{2}$ (program SHELXL97 (26)). All non-hydrogen atoms were refined anisotropically. $\mathrm{H}$ atoms were included using a riding model. Refinement proceeded to $w R\left(F^{2}\right) 0.0616$, conventional $R(F) \quad 0.0307$ for 222 parameters, $S\left(F^{2}\right)=0.952$, maximum $\Delta \rho=1.634$ e $\AA^{-3}$. Complete crystallographic data have been deposited at the Cambridge Crystallographic Data Centre (CCDC-749817). Copies may be requested free of charge via www.ccdc.cam.ac.uk/data_request/cif.

\section{Results and discussion}

The ligand 1,1-bis[N,N'-(2-diphenylphosphino) amide]ferro-cene, $\mathrm{Fc}\left(\mathrm{CONHCH}_{2} \mathrm{CH}_{2} \mathrm{PPh}_{2}\right)_{2}$, has been prepared by treatment of the 1,1'-bis (chlorocarbonyl) ferrocene derivative with 2-(diphenylphosphino)ethylamine, in a 1:2 molar ratio in dichloromethane in the presence of $\mathrm{NEt}_{3}$ (see Equation 1). The IR spectrum shows two $\mathrm{v}(\mathrm{C}=\mathrm{O})$ absorptions at 1633 (s) and 1623 (s) $\mathrm{cm}^{-1}$ and the vibration $\mathrm{v}(\mathrm{NH})$ at $3268(\mathrm{~m}) \mathrm{cm}^{-1}$. The ${ }^{1} \mathrm{H}$ NMR spectrum shows two multiplets for the two methylene groups of the phosphine at 2.60 and $3.62 \mathrm{ppm}$ and two multiplets for the $\alpha$ and $\beta$-protons of the substituted cyclopentadienido group at 4.33 and 4.51, respectively. The amido $\mathrm{NH}-\mathrm{CO}$ protons appear at $7.12 \mathrm{ppm}$. The ${ }^{31} \mathrm{P}\{1 \mathrm{H}\}$ NMR spectrum presents one singlet for the equivalent phosphorus atoms at $-19.0 \mathrm{ppm}$.

The reaction of $\mathrm{Fc}\left(\mathrm{CONHCH}_{2} \mathrm{CH}_{2} \mathrm{PPh}_{2}\right)_{2}$ with $\left[\mathrm{Cu}(\mathrm{NCMe})_{4}\right] \mathrm{PF}_{6}$ or $\mathrm{Ag}(\mathrm{OTf})(\mathrm{OTf}=$ trifluoromethane sulphonate) in a molar ratio $1: 1$ gives the complexes $\left[\mathrm{Cu}\left\{\mathrm{Fc}\left(\mathrm{CONHCH}_{2} \mathrm{CH}_{2} \mathrm{PPh}_{2}\right)_{2}\right\}\right] \mathrm{PF}_{6}(\mathbf{1})$ or $[\mathrm{Ag}(\mathrm{OTf})\{\mathrm{FC}$ $\left.\left.\left(\mathrm{CONHCH}_{2} \mathrm{CH}_{2} \mathrm{PPh}_{2}\right)_{2}\right\}\right]$ (2) (see Scheme 1). Although the stoichiometry of these complexes is similar we assume different structures, taking into account the

\section{Equation 1}

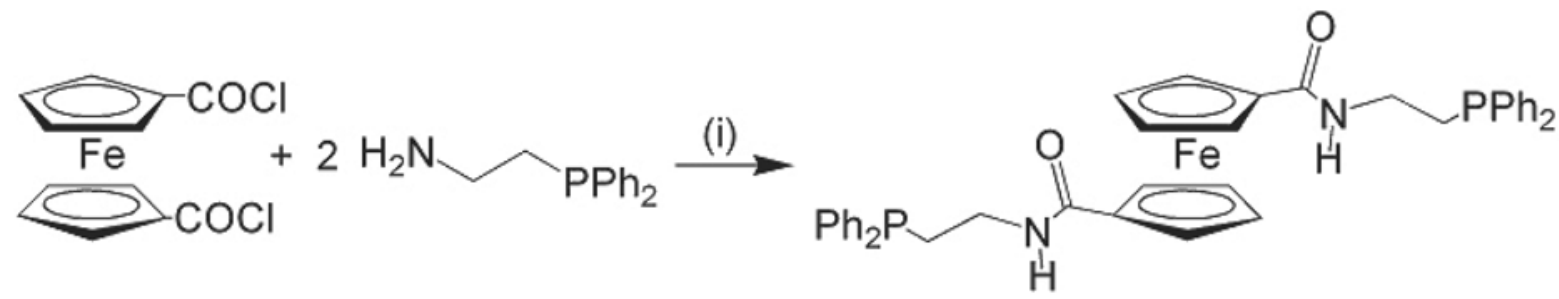

(i): $\mathrm{NEt}_{3}, \mathrm{CH}_{2} \mathrm{Cl}_{2}$ dest. 


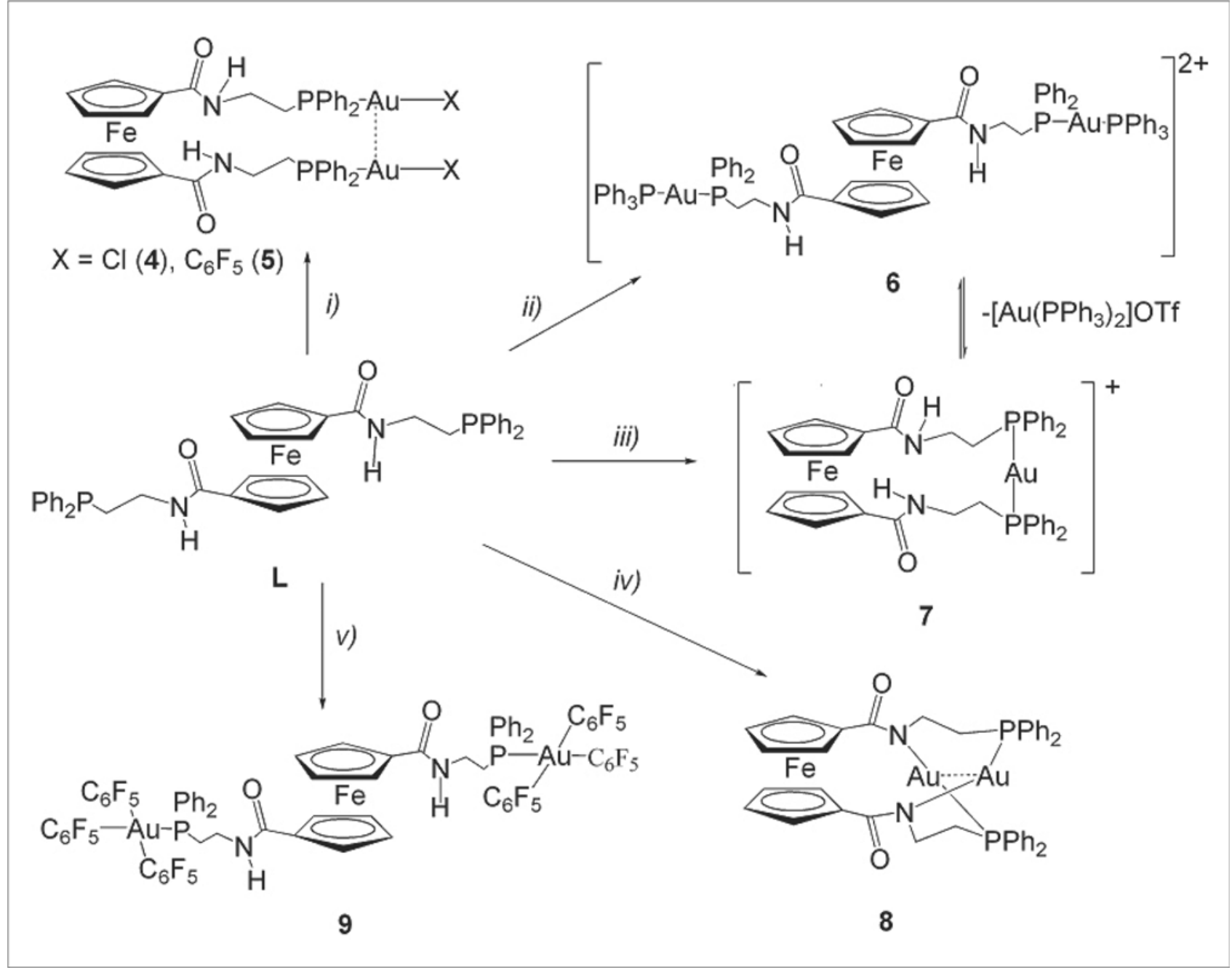

i) $2[\mathrm{AuX}($ tht $)]\left(X=\mathrm{Cl}, \mathrm{C}_{6} \mathrm{~F}_{5}\right)$, ii) $2\left[\mathrm{Au}(\mathrm{OTf})\left(\mathrm{PPh} \mathrm{h}_{3}\right)\right]$, iii) $\left[\mathrm{Au}(\text { tht })_{2}\right] \mathrm{OTf}$, iv) $\left.\left.\left[\mathrm{O}(\mathrm{AuPPh})_{3}\right)_{3}\right] \mathrm{ClO}_{4}, v\right) 2\left[\mathrm{Au}\left(\mathrm{C}_{6} \mathrm{~F}_{5}\right)_{3}\left(\mathrm{OEt} \mathrm{t}_{2}\right)\right]$

different coordination properties of the anion, and that for the copper complex the ligand coordinates to the metallic center through their four donor atoms eg. the amino and phosphino groups, and for the silver the structure probably corresponds to trigonal planar silver complex with a coordinated triflate, although a dimer structure with the phosphines acting as chelate and bridging triflate ligands is possible in the solid state; this structure has been found for us in many silver(I) complexes with bidentate ferrocene ligands (27). The IR spectra presents the absorptions for the $\mathrm{NH}$ at around 3345 $(\mathrm{m})$, the $\mathrm{v}(\mathrm{C}=\mathrm{O})$ at $1633(\mathrm{~s}) \mathrm{cm}^{-1}$, and for 2 those for the coordinated triflate anion at 1287 and 1252 (vs), $v_{\text {asym }}\left(\mathrm{SO}_{3}\right), 1221(\mathrm{~m}), v_{\text {sym }}\left(\mathrm{CF}_{3}\right), 1158(\mathrm{~s}), v_{\text {asym }}\left(\mathrm{CF}_{3}\right)$, and 1029 (vs), $v_{\text {sym }}\left(\mathrm{SO}_{3}\right)$. The ${ }^{1} \mathrm{H}$ NMR spectrum shows similar resonances as those in the ligand but with a different chemical shift. The ${ }^{31} \mathrm{P}\left\{{ }^{1} \mathrm{H}\right\} \quad \mathrm{NMR}$ spectra present a singlet at -8.0 ppm for complex 1 and one broad resonance around $-1.0 \mathrm{ppm}$ that does not split into the typical two doublets for Ag-P complexes even at low temperature $\left(-60^{\circ} \mathrm{C}\right)$ for complex 2. The liquid secondary ion mass spectra (LSIMS+) show the cation molecular peaks [CuL] ${ }^{+}$at $\mathrm{m} / \mathrm{z}=759(100 \%)$ and $[\mathrm{AgL}]^{+}$at $\mathrm{m} / \mathrm{z}=803(100 \%)$.

Treatment of $\mathrm{Fc}\left(\mathrm{CONHCH}_{2} \mathrm{CH}_{2} \mathrm{PPh}_{2}\right)_{2}$ with $\left[\mathrm{Ag}(\mathrm{OTf})\left(\mathrm{PPh}_{3}\right)\right]($ molar ratio 1:1) affords the complex $\left[\mathrm{Ag}(\mathrm{OTf})\left\{\mathrm{FC}\left(\mathrm{CONHCH}_{2} \mathrm{CH}_{2} \mathrm{PPh}_{2}\right)_{2}\right\}\left(\mathrm{PPh}_{3}\right)\right](3)$. Presumably the complex is mononuclear with the silver center in a tetrahedral geometry and the diphosphine acting as chelate and the triflate as monodentate. The IR spectrum presents the absorptions for the $\mathrm{NH}$ at $3351(\mathrm{~m})$, the $\mathrm{v}(\mathrm{C}=\mathrm{O})$ at 
1632 (s) $\mathrm{cm}^{-1}$, and those for the coordinated triflate anion at 1286 and 1253 (vs), $v_{\text {asym }}\left(\mathrm{SO}_{3}\right), 1224(\mathrm{~m})$, $v_{\text {sym }}\left(\mathrm{CF}_{3}\right), 1165$ (s), $v_{\text {asym }}\left(\mathrm{CF}_{3}\right)$, and 1029 (vs), $v_{\text {sym }}\left(\mathrm{SO}_{3}\right)$. The ${ }^{1} \mathrm{H}$ NMR spectrum presents the typical pattern for the ligand $\mathbf{L}$. The ${ }^{31} \mathrm{P}\left\{{ }^{1} \mathrm{H}\right\}$ NMR spectrum presents one broad resonance around $8.12 \mathrm{ppm}$ that is not resolved completely at $-90^{\circ} \mathrm{C}$, although points out at $A B_{2}$ system coupled to both silver nuclei. The liquid secondary ion mass spectrum (LSMS+) shows the cation molecular peak $\left[\mathrm{AgL}\left(\mathrm{PPh}_{3}\right)\right]^{+}$at $\mathrm{m} / \mathrm{z}=1066(51 \%)$ and the most intense is the fragment $[\mathrm{AgL}]^{+}$at $\mathrm{m} / \mathrm{z}=803(100 \%)$.

The reactivity towards the gold compounds [AuX(tht)] $\left(\mathrm{X}=\mathrm{Cl}, \mathrm{C}_{6} \mathrm{~F}_{5}\right)$ has also been studied and thus the treatment of $\mathrm{FC}\left(\mathrm{CONHCH}_{2} \mathrm{CH}_{2} \mathrm{PPh}_{2}\right)_{2}$ with two equivalents of $[\mathrm{AuX}(\mathrm{tht})]$ leads to the dinuclear gold complexes with the diphosphine acting as bridging ligand, $\left[\mathrm{Au}_{2} \mathrm{X}_{2}\left\{\mathrm{\mu}-\mathrm{Fc}\left(\mathrm{CONHCH}_{2} \mathrm{CH}_{2} \mathrm{PPh}_{2}\right)_{2}\right)\right]$ $\left(X=\mathrm{Cl}(\mathbf{4}), \mathrm{C}_{6} \mathrm{~F}_{5}(\mathbf{5})\right.$ ) (see Scheme 2). Their IR spectra show the absorptions for the $\mathrm{NH}$ group at $3347(\mathrm{~m})$ and $3368(\mathrm{~m}) \mathrm{cm}^{-1}$, respectively; additionally the $v(\mathrm{Au}-\mathrm{Cl})$ appears at 330 (m) $\mathrm{cm}^{-1}$ for complex 4 and those due to the pentafluorophenyl group in 5 at 1501 (vs), 953 (vs) and $888(\mathrm{~m}) \mathrm{cm}^{-1}$. The ${ }^{1} \mathrm{H}$ and ${ }^{31} \mathrm{P}\left\{{ }^{1} \mathrm{H}\right\}$ NMR spectra presents the resonances for the protons and the phosphorus of the ligand, respectively, with a different chemical shift. The ${ }^{19} \mathrm{~F}$ NMR spectrum of 5 shows equivalent pentafluorophenyl groups and thus two multiplets for the orto and meta fluorine and a triplet for the para fluorine appears. The mass spectra show the molecular peaks at $\mathrm{m} / \mathrm{z}=1160$ $(24 \%, 4), 1424(28 \%, 5)$.

The reaction of $\mathrm{FC}\left(\mathrm{CONHCH}_{2} \mathrm{CH}_{2} \mathrm{PPh}_{2}\right)_{2}$ with $\left[\mathrm{Au}(\mathrm{OTf})\left(\mathrm{PPh}_{3}\right)\right]$ in a molar ratio $1: 2$ gives the dinuclear derivative $\left[\mathrm{Au}_{2}\left\{\mu-\mathrm{Fc}\left(\mathrm{CONHCH}_{2} \mathrm{CH}_{2} \mathrm{PPh}_{2}\right)_{2}\right\}\right.$ $\left.\left(\mathrm{PPh}_{3}\right)_{2}\right](\mathrm{OTf})_{2}(\mathbf{6})$. The IR spectrum presents the absorption at 3337 (s) $\mathrm{cm}^{-1}$ for the amide group and the vibration $v(C=0)$ at 1639 , apart from those arising at the uncoordinated triflate anion. The NMR spectrum shows a major product that is complex 6 and another compound which is present as a minor component. The ${ }^{31} \mathrm{P}\left\{{ }^{1} \mathrm{H}\right\}$ NMR spectrum at room temperature is interesting because it shows two different resonances; in the low temperature spectrum an $A B$ system can be observed due to the $\mathrm{Ph}_{2} \mathrm{P}-\mathrm{AuPPh}$ unit and also two more resonances that are attributable to the species shown in Scheme 2 in which complex $\mathbf{6}$ is in equilibria with the species coming from the loss of the fragment $\left[\mathrm{Au}\left(\mathrm{PPh}_{3}\right)_{2}\right]^{+}$, $\left[\mathrm{Au}\left\{\mathrm{FC}\left(\mathrm{CONHCH}_{2} \mathrm{CH}_{2} \mathrm{PPh}_{2}\right)_{2}\right\}\right] \mathrm{OTf}$ (7). The mass spectrum presents the cation $\left[\mathrm{Au}_{2}(\mathrm{OTf})\right.$
$\left.\left\{\mathrm{FC}\left(\mathrm{CONHCH}_{2} \mathrm{CH}_{2} \mathrm{PPh}_{2}\right)_{2}\right\}\left(\mathrm{PPh}_{3}\right)_{2}\right]^{+}$at $\mathrm{m} / \mathrm{z}=1763$ $(25 \%)$ originated by the loss of a triflate anion. To prove the existence of complex $\mathbf{7}$ we have prepared it deliberately by reaction of the ligand with one equivalent of $\left[\mathrm{Au}(\mathrm{tht})_{2}\right] \mathrm{OTf}$ that affords complex $\left[\mathrm{Au}\left\{\mathrm{Fc}\left(\mathrm{CONHCH}_{2} \mathrm{CH}_{2} \mathrm{PPh}_{2}\right)_{2}\right\}\right]$ OTf (7) in good yield. The spectroscopic data agrees with the minor component shown in the synthesis of complex $\mathbf{6}$. For this compound we propose a mononuclear structure with the ligand acting as trans-chelate, as we have previously reported this type of situation in gold with other ferrocene-base ligands (28).

The treatment of $\mathrm{FC}\left(\mathrm{CONHCH}_{2} \mathrm{CH}_{2} \mathrm{PPh}_{2}\right)_{2}$ with the oxonium compound $\left[\mathrm{O}\left(\mathrm{AuPPh}_{3}\right)_{3} \mathrm{ClO}_{4}\right.$ produces the deprotonation of the nitrogen atoms of the amides and coordination of the gold atoms in a head-to-tail manner to the dianionic ligand by displacement of the triphenylphosphine giving $\left[\mathrm{Au}_{2}\{\mathrm{FC}\right.$ $\left.\left.\left(\mathrm{CONCH}_{2} \mathrm{CH}_{2} \mathrm{PPh}_{2}\right)_{2}\right\}\right]$ (8). The IR spectrum shows the absence of the $\mathrm{NH}$ absorption and also in the ${ }^{1} \mathrm{H}$ NMR spectrum this resonance has disappeared. The ${ }^{31} \mathrm{P}\left\{{ }^{1} \mathrm{H}\right\}$ NMR spectrum presents one unique signal at 19.2 for the two equivalent phosphorus. In the mass spectrum the molecular peak plus one proton can be observed at $\mathrm{m} / \mathrm{z}=1089$ (15\%).

Complex 8 crystallizes in the orthorhombic system with the Fe atom of the ferrocene ligand lying on a twofold symmetry axis; consequently its asymmetric unit cell contains half of the molecule (Figure 1

Figure 1: Molecular structure of complex 8

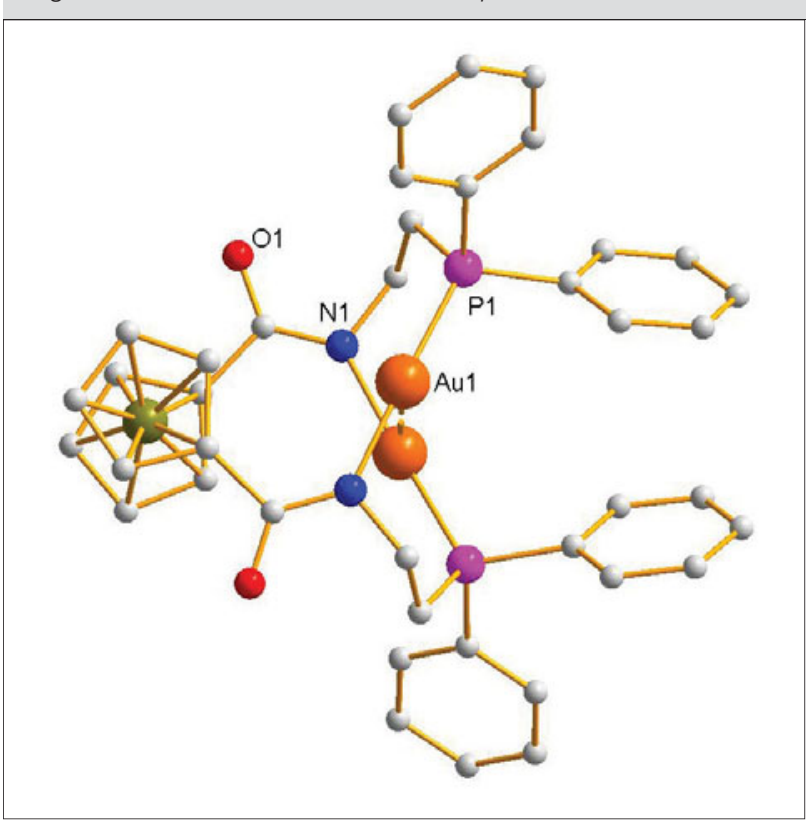


shows the molecule generated by symmetry). The gold $(I)$ atom is bonded to the amido nitrogen of one of the phosphine chains and to the phosphorous atom of the other. The geometry around the gold atom is almost linear as shown by the angle P-Au-N $176.61^{\circ}(19)$. The deviation from linearity may be due to the strong interaction between the two gold atoms (Au-Au distance $=2.8921(5) \AA$ ).

The Au-N (2.052(6) Å) and Au-P (2.225(2) $\AA$ ) distances compare well with those found in other gold(I) derivatives with the unit N-Au-P (29) such as

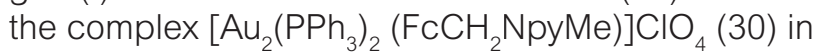
which one of the gold atoms is attached to the amino nitrogen at 2.052(5) $\AA$ and to the phosphorus atom of one triphenylphosphine ligand at 2.2412(16) A. The two cyclopentadienyl rings are essentially eclipsed and deviated only slightly from being parallel (the mean torsional angle $\mathrm{C} 1-\mathrm{X} 1-\mathrm{X} 2-\mathrm{C} 2 \mathrm{~A}$ is $5.7^{\circ}$, where $\mathrm{X} 1$ and $\mathrm{X} 2$ are the centres of the cyclopentadienyl rings; the angle between the best planes of atoms $\mathrm{C} 1-\mathrm{C} 5$ and $\mathrm{C} 1 \mathrm{~A}-\mathrm{C} 5 \mathrm{~A}$ is $1.3^{\circ}$ ). The corresponding angle $\mathrm{C} 1-\mathrm{X} 1-\mathrm{X} 2-\mathrm{C} 1 \mathrm{~A}$ is $91^{\circ}$. The distances of the $\mathrm{Fe}$ atom to the centres of the $\mathrm{Cp}$ rings are 1.632 $\AA$. The gold atom is located close to and with short contacts to the $\mathrm{C} 1-\mathrm{C} 2$ bond of the cyclopentadienyl group (distances to C1 and C2: 3.405 and $3.197 \AA$ ) indicating a weak $\eta 2$ interaction with the $\mathrm{Cp}$ ring in a similar manner as has been observed in other gold and silver complexes with ferrocene derivatives. (31) The structure also presents a short intermolecular hydrogen bond $[\mathrm{H} 23 \ldots . \mathrm{O}(1) \#(\#:$ : 1+x, 0.5-y, z-0.5) $2.32 \AA$ Aं; $\left.\mathrm{C} 23-\mathrm{H} 23 \ldots \mathrm{O}(1) 165.9^{\circ}\right]$

The gold(III) derivative $\left[\mathrm{Au}_{2}\left(\mathrm{C}_{6} \mathrm{~F}_{5}\right)_{6}\left\{\mathrm{Fc}\left(\mathrm{CONHCH}_{2} \mathrm{CH}\right.\right.\right.$ $\left.\left.\left.{ }_{2} \mathrm{PPh}_{2}\right)_{2}\right\}\right]$ (9) has also been synthesized by reaction of the ligand with $\left[\mathrm{Au}\left(\mathrm{C}_{6} \mathrm{~F}_{5}\right)_{3}\left(\mathrm{OEt}_{2}\right)\right]$ in a molar ratio 1:2. The spectroscopic data corroborates the coordination of the tris(pentafluorophenyl) fragments to both phosphorus atoms giving a dinuclear derivative with the ligand bridging both gold centers.

\section{Conclusions}

The synthesis of the new hemilabile diphosphine ligand $\mathrm{Fc}\left(\mathrm{CONHCH}_{2} \mathrm{CH}_{2} \mathrm{PPh}_{2}\right)_{2}$ and their coordination properties towards group 11 metals have been studied. This ligand shows a great variety of coordination modes as bidentate bridging or transchelate ligand, as tetradentate neutral ligand and also as tetradentate N,N,P,P dianionic ligand. The structure of $\left[\mathrm{Au}_{2}\left\{\mathrm{Fc}\left(\mathrm{CONCH} \mathrm{CH}_{2} \mathrm{PPh}_{2}\right)_{2}\right\}\right]$ (8) have been solved showing a dinuclear species with the gold coordinated to the amide and phosphorus atoms and also with a short aurophilic contact.

\section{Acknowledgements}

We thank the Ministerio de Ciencia e Innovación (CTQ2007-67273-C02-01) for financial support.

\section{About the authors}

The group in the University of Zaragoza is working in gold chemistry since 1970 and they have produced more than 350 scientific papers. They focus their interest not only in the synthesis of new homo- and hetero-nuclear gold compounds, but also in the study of the optical or biological properties. Some of them have been invited to give talks at different International Conferences or Universities in America, Asia or Europe.

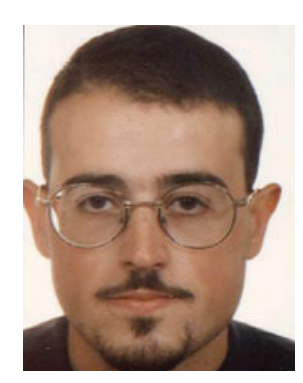

Javier E. Aguado

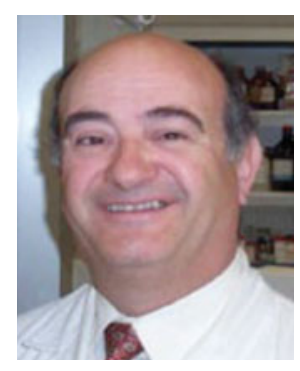

Antonio Laguna

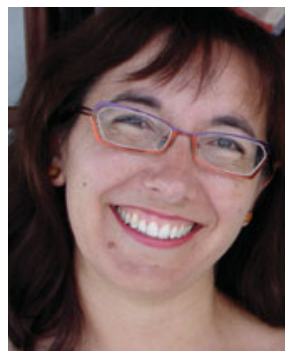

M. Concepción Gimeno

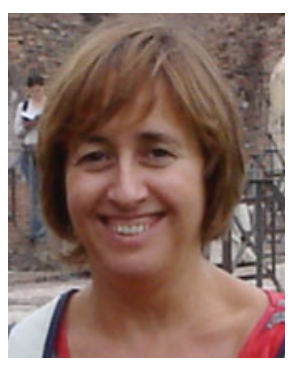

M. Dolores Villacampa

\section{References}

1 a) A. Togni, T. Hayashi, eds., Ferrocenes, Homogeneous Catalysis, Organic Synthesis and Materials Science, VCH, Weinheim, 1995. b) A. Togni, R.L. Halterman, eds., Metallocenes, VCH, Weinheim, 1998. c) N.J. Long. Metallocenes, An Introduction to Sandwich Complexes, Blackwell Science, Oxford, 1998

2 N.J. Long, Angew. Chem. Int. Ed. 1995, 34, 21

3 I. Manners, Adv. Organomet. Chem. 1995, 37, 131

4 I. Manners, Chem. Commun. 1999, 857

5 Y. Zhu, Y. Clot, M.O. Wolf, G.P.A. Yap, J. Am. Chem. Soc. 1998, 120, 1812

6 P.D. Beer, Acc. Chem. Res. 1998, 31, 71 
7 P.D. Beer, P.A. Gale, G.Z. Chen, J. Chem. Soc., Dalton Trans. 1999, 1897

8 R.V. Honeychuck, M.O. Okoroafor, L.H. Shen, C.H. Brubaker, Jr, Organometallics 1986, 5, 482

9 A.C. Templeton, W.P. Wuelfing, R.W. Murray, Acc. Chem. Res. 2000, 33, 27

10 R.S. Ingram, M.J. Hostetler, R.W. Murray, J. Am. Chem. Soc. 1997, 119, 9175

11 I. Willner, E. Katz, Angew. Chem. Int. Ed. Engl. 2000, 39, 1180

12 A. Tarraga, P. Molina, J.L. López, M.D. Velasco, D. Bautista, Organometallics 2002, 21, 2055

13 C.E. Inmoos, S.J. Lee, M.W. Grinstaff, J. Am. Chem. Soc. 2004, 126, 10814

14 R.H. Fisher, G. Jaouen, Organometallics 2003, 22, 2166

15 D.R.V. Staveren, N. Metzler-Nolte, Chem. Rev. 2004, 104, 5931

16 A.M. Allgeier, C.S. Slone, C.A. Mirkin, L.M. Liable-Sands, G.P.A. Yap, A.L. Rheingold, J. Am. Chem. Soc. 1997, 119, 550

17 P.L. Paulson, W.E. Watts, J. Chem. Soc. 1963, 2990

18 G.J. Kubas, Inorg. Synth. 1979, 19, 90

19 M.I. Bruce, B.K. Nicholson, O.B. Shawkataly, Inorg, Synth. 1989, 26, 324

20 R. Usón, A. Laguna, Inorg. Synth. 1982, 21, 71

21 R. Usón, A. Laguna, M. Laguna, Inorg. Synth. 1989, 26, 85

22 R. Usón, A. Laguna, M. Laguna, J. Jiménez, M.E. Durana, Inorg. Chim. Acta, 1990, 168, 89

23 C. Aguirre, M.C. Gimeno, A. Laguna, M. Laguna, J.M. López de Luzuriaga, F. Puente, Inorg. Chim. Acta 1993, 208, 31

24 M. Bardají, O. Crespo, A. Laguna, A.K. Fischer, Inorg. Chim. Acta, 2000, 304, 7
25 G.M. Sheldrick, SADABS, Program for absorption correction, University of Göttingen, Göttingen, Germany, 1996

26 M. Sheldrick, SHELXL-97, A program for Crystal Structure Refinement, University of Gottingen, Germany, 1997

27 a) S. Canales, O. Crespo, A. Fortea, M.C. Gimeno, P.G. Jones, A. Laguna, Dalton Trans. 2002, 2250. b) M.C. Calhorda, P.J. Costa, P.N. Martinho, M.C. Gimeno, A. Laguna, S. Quintal, M.D. Villacampa, J. Organomet. Chem. 2006, 691, 4181

28 a) M.C. Gimeno, P.G. Jones, A. Laguna, C. Sarroca, J. Chem. Soc. Dalton Trans. 1995, 3563. b) S. Canales,

O. Crespo, M.C. Gimeno, P.G. Jones, A. Laguna, J. Organomet. Chem. 2000, 613, 50

29 a) A.A. Mohamed, J.M. López de Luzuriaga and J.P. Fackler, Jr., J. Cluster Science, 2003, 14, 61. b) F. Bachechi, A. Burini, R. Galassi, B.R. Pietroni and M. Severini, J.Organomet. Chem., 1999, 575, 269.

c) K. Nomiya, R. Noguchi, K. Ohsawa, K. Tsuda and M. Oda, J. Inorg. Biochem., 2000, 78, 363. d) P. Ovejero, M. Cano, E. Pinilla and M.R. Torres, Helv. Chim. Acta, 2002, 85, 1686. e) O. Crespo, M.C. Gimeno, P.G. Jones, A. Laguna, M. Naranjo and M.D. Villacampa, Eur. J. Inorg. Chem., 2008, 5408

30 E.M. Barranco, O. Crespo, M.C. Gimeno, P.G. Jones and A. Laguna, Eur. J. Inorg. Chem., 2004, 4820

31 a) O. Crespo, M.C. Gimeno, P.G. Jones, A. Laguna and C. Sarroca, Chem. Commun., 1998, 1481. b) M.C. Gimeno, P.G. Jones, A. Laguna, C. Sarroca, M.J. Calhorda and L.F. Veiros, Chem. Eur. J., 1998, 4, 2308 